\title{
Antiquities in a time of conflict: a crime script analysis of antiquities trafficking during the Syrian Civil War and implications for conflict antiquities
}

\author{
Christine A. Weirich* ${ }^{*}$
}

\begin{abstract}
The Syrian Civil War created an opportunity for increased trafficking of antiquities and has resulted in a renewed awareness on the part of a global audience. The persistence of criminal and organisational networks which facilitate antiquities trafficking networks (ATNs) has been recognised as significant, leading to increased interest in the development of new and improved methods of understanding such networks. While this field of research has traditionally been dominated by relevant areas such as archaeology, law, art and museum studies, there is a noticeable gap in crime prevention research. This paper presents a crime script of Syrian antiquities trafficking networks during the Syrian Civil War which has been generated from open source journalistic data. In creating a broad crime script for such a prevalent issue, this paper aims to demonstrate the need for further crime script analysis and specifically crime prevention research more generally within the study of antiquities trafficking.
\end{abstract}

Keywords: Crime script analysis, Antiquities trafficking, Illicit antiquities, Crime prevention, Illicit networks

\section{Introduction: the nature of antiquities trafficking networks (ATNs)}

Antiquities Trafficking Networks (ATNs) is a term used to refer to the looting, trafficking, and selling of illicit antiquities. Illicit antiquities can be defined as "archaeological objects that have been illegally excavated or exported from their country of origin for monetary gain" (Brodie 2018, para. 1). Essentially, this refers to any cultural, historical, or archaeological object which is illegally excavated. Antiquities trafficking represents an illicit network that occurs on a global scale, and which operates as a grey market, meaning that it operates in the grey area between legal and illicit markets (Mackenzie et al. 2019). For example, the term 'black market' is often used to refer

\footnotetext{
*Correspondence: Christine.Weirich@gmail.com

Centre for Criminal Justice Studies (CCJS), University of Leeds, Leeds LS2 9JT, UK
}

to a market which operates outside of legal market-or in an illegal manner, as the antiquities market is self-regulated. With no incentives to enforce strict buying/selling procedures, the consequence is the antiquities market operating within the grey area between licit and illicit. In recent years, more criminological research has been conducted on ATNs and this work has served to document important aspects of the trade-including the recognition that ATNs operate as organised crime, are transnational in nature, and are a grey market (as opposed to a black market or a legitimate market) (Alder and Polk 2005; Mackenzie et al. 2019)

Previous prevention literature within the field of antiquities trafficking has prominently focused on policy or market-targeted measures, with a focus on controlling or reducing specific types of objects being sold or traded on the antiquities market-such as Iraqi antiquities following the 2003 looting of the National Museum of Iraq

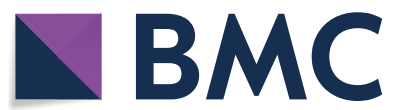

(c) The Author(s) 2021. This article is licensed under a Creative Commons Attribution 4.0 International License, which permits use, sharing, adaptation, distribution and reproduction in any medium or format, as long as you give appropriate credit to the original author(s) and the source, provide a link to the Creative Commons licence, and indicate if changes were made. The images or other third party material in this article are included in the article's Creative Commons licence, unless indicated otherwise in a credit line to the material. If material is not included in the article's Creative Commons licence and your intended use is not permitted by statutory regulation or exceeds the permitted use, you will need to obtain permission directly from the copyright holder. To view a copy of this licence, visit http://creativeco mmons.org/licenses/by/4.0/. The Creative Commons Public Domain Dedication waiver (http://creativecommons.org/publicdomain/ zero/1.0/) applies to the data made available in this article, unless otherwise stated in a credit line to the data. 
in Baghdad (Brodie 2011). They have largely targeted the most visible area of the network - the end of the process, namely the antiquities market. Moreover, while previous studies and the general literature related to ATNs has served to identify some of the major factors which allow these networks to continue, there has been little criminological research focused specifically on realistic or effective potential prevention measures targeting earlier stages of transactions within the networks (Grove and Pease 2014; Polk 2009, 2014).

\section{Antiquities trafficking networks in the context of the Syrian Civil War}

The Syrian conflict has become a prominent issue of both research and discussion within this field. There have been major strides taken in research specific to the documentation and preservation of heritage during conflicts and preservation (Casana and Panahipour 2014; Contreras and Brodie 2010; Parcak et al. 2016; Rayne et al. 2017). In reference to the Syrian conflict there was particular interest in reports that terrorist groups may have participated in organised antiquities trafficking with reports of mass looting and the city of Aleppo, once a World Heritage Site, having been all but destroyed; the firebombing of the Old City Bazaar; and the extreme destruction and damage which occurred at the ancient city of Palmyra (Harkin 2016; Bilefsky 2017). A number of research and interest groups have been created specifically to consider antiquities and cultural heritage within the Syrian conflict, as a result of lessons learned from the looting of the Baghdad Museum in the Iraq War of 2003 (Leckie et al. 2017). As much global attention and journalistic literature centred on the Syrian conflict, this provides a large volume of non-academic materials to develop a crime script analysis of Syrian antiquities trafficking networks.

\section{Methods}

This project makes use of crime scripting to better understand more fully the details of how antiquities trafficking occurs within the Syrian Conflict. Crime scripting can best be described as an analytic tool which scripts the required actions for a crime to occur (Cornish 1994). The crime script format allows for analysis not only of the actors and actions required for a crime to take place, but also provides a framework to better understand potential points of prevention. As such, it provides a useful tool in comprehending a complex issue such as antiquities trafficking.

The initial development of this project drew upon aspects of previous research which utilized crime scripting to help provide constraints and scope to crime prevention research (Chiu et al. 2011a; Fabiani, 2016; Gilmour, 2014; Hutchings and Holt 2015a; Jacques and
Bernasco, 2013; Lavorgna, 2014, 2015a; Leontiadis and Hutchings 2015; Tompson and Chainey 2011; Unal 2009). Specifically, the format of crime scripting used here has been drawn from research that provides general crime scripts, organized through a broad range of activities (or variables) into different categories which are then examined more in-depth in the scripting process.

These studies demonstrate that crime scripting can vary from extremely detailed instances, to also representing broad areas of criminal activity, as in the case of child sex trafficking and drug laboratories (Brayley et al. 2011; Chiu et al. 2011a). It is evident that scripts were developed either (1) after thorough analysis of the entire data set at once, or (2) on a rolling basis, with adjustments being made as more data was analysed. This project employed a combination of both, as it began with a simple model of antiquities trafficking using data from wellstudied cases, and applies and adapt this model based on the data relating to Syria. With no standard format to inform how the script should appear or operate, the development of the various elements of the script (stages, format, and content) were constructed and adapted as a result of the data (Borrion 2013; Dehghanniri and Borrion 2017). The critical methodological considerations involve the selection of (a) a script type; ((b) data sources and content analysis; (c) data sources; and (d) script development.

\section{Script type}

In the course of assembling the crime script that would be used in this project, a number of studies which generated crime scripts were examined (Chiu et al. 2011a, 2011b; Tompson and Chainey 2011b; Brodie 2012; Brodie et al. 2013; Jacques and Bernasco 2013; Gilmour, 2014; Lavorgna, 2014; Hutchings and Holt 2015a, 2015b; Leontiadis and Hutchings 2015; Lavorgna 2015a, 2015b). These studies were able to produce crime scripts from data and research available to their field of study-generally consisting of interviews and case studies. Within antiquities trafficking research a prevalent source of data is investigative journalism or journalistic articles.

One of the main strengths of crime scripting is its adaptability, and ability to focus on specialized forms of crime. This also creates the challenge of developing a standardized method of constructing and using crime scripts. When considering the different ways that previous researchers have developed their crime scripts, it was evident that the quality of data had a direct influence on the final structure of the crime script. When considering the data available in the development of a Syrian antiquities trafficking crime script it was evident that available data did not cover a complete script (looting to market), but portions or snapshots of how the network operated. 
Generating a crime script out of multiple snapshots could lead to misinterpreting the data or the structure of the market. As such, it was determined that a potential crime script (envisioning alternative permutations), rather than a preformed or fully-planned script (envisioning just a single track) would be the most effective means of interpreting the data in a way so as not to misrepresent or narrow the overall structure of ATNs. This allows for a consideration of the various options that a criminal may take in order to achieve a crime, so as to gain a better understanding of how an offender would choose his/ her method of choice (Borrion 2013). The main focus of this script is to demonstrate the ways in which antiquities trafficking could occur, demonstrating the hypotheticals of the situation, while being informed by the only source available-in this case journalistic sources. This script is intended to be used as a starting point, with the hope that further research may be able to generate increasingly accurate and specific scripts. Therefore, even with the use of 'multiple snapshots', the use of a predictive crime script will still effectively reflect the relevant data while also considering the numerous possibilities of antiquities trafficking which may have occurred during this time.

\section{Data source \& analysis}

Typically, the creation of crime scripts has been derived from data sources such as case files, police records, or interviews (de Bie et al. 2015; Jacques and Bernasco 2013; Lavorgna 2014; Petrossian 2014; Shukla and Bartgis 2010). Due to a lack of data pertaining to antiquities trafficking, these more traditional and rigorous sources were not a viable option for this research project. Investigative journalism has played a large role in gathering data and producing evidence of ATNs, and as a result, this project focused on digital media as a data source. Using digital media as a source of data for the development of the crime scripts presented the difficulty of inherent bias, as media content is generated with a very different motivation than empirical research. This issue as will be described has been acknowledged in the resulting crime script, as ultimately this data was deemed too valuable to be overlooked.

Content analysis was used as a means of analysing secondary open source data-in the form of journalistic articles (Chang et al. 2014). This was achieved by determining relevant articles and then extracting or highlighting significant terms or processes (pertinent to antiquities trafficking) to develop the crime scripts. The primary source of data for the development of the crime scripts were open source journalistic articles, which were gathered using public web searches. Content analysis is commonly used as a means of analysing sections of texts or documents in order to examine frequency of word use, or specific language (Crowther-Dowey and Fussey 2013; Maxfield and Babbie 2012). In the case of this project, content analysis was used to determine common words, phrases, or themes associated with antiquities trafficking activities or actions. The scripts that were developed from this analysis then reflected specific types of actions or elements that occurred in the process of a crime being committed, and were present in the text, ultimately informing how the script of antiquities trafficking occurred. As such, the analysis which took place was closely aligned to content analysis but differed subtly from its traditional aims by targeting specific actions or processes rather than word frequency or value.

\section{Data collection}

In collecting data for crime scripts, a search was conducted through Google of all English language specific news articles between January 1, 2005 to December 31st, 2016 using these key search terms listed in the table below (Fig. 1).

Specifically, the type of data that was being targeted was direct quotes or paraphrasing from individuals involved in ATNs in some way.

The date range was chosen to include years prior to the beginning of the Syrian Civil War. This was partly to demonstrate the visible increase in articles being generated concerning Syrian cultural heritage and antiquities after the outbreak of fighting, but also to see if any data could be retrieved to establish the type of looting or trafficking of antiquities prior to the outbreak of the war. Antiquities trafficking did occur prior to the conflict, and the method by which this looting occurred would likely have been different from the types of trafficking that appears in the Syria script-which may have allowed for a valuable comparison between a 'before' and 'after' scripts for this region-unfortunately, such a comparison was not achievable due to lack detailed data prior to the conflict's start.

Once a complete dataset was collected, the results were entered into a spreadsheet in order to organise and determine viable data. The data was coded, examined thoroughly, and crime scripts were developed based upon the direct quotes and paraphrasing that existed in the

\begin{tabular}{|l|l|l|l|}
\hline antiquities & heritage AND smuggler & illegal & looters \\
\hline antiquity & smuggling & illicit AND Syria & looted \\
\hline object & smuggled & Syrian AND dealer & looting \\
\hline $\begin{array}{l}\text { artifact } \\
\text { cutlure }\end{array}$ & smugglers & market & $\begin{array}{l}\text { stolen AND } \\
\text { trafficked }\end{array}$ \\
\hline cultural & black market' & trade & trafficking \\
\hline
\end{tabular}

Fig. 1 Search Terms of Syrian Crime Script 
journalistic articles. Viable data was determined by the following criteria:

(1) Did the article include either direct quotes or paraphrasing from individuals involved in antiquities trafficking;

(2) And was there enough data within the article to help inform the crime script.

This search compiled a total of 492 results, of which 226 were examined for further data. The 266 that were eliminated at this stage was a result of not being directly relevant to the search parameters-including non-relevant blogs, reposting of media articles, or official announcements or reports/press reports by international organizations that often repeated or lacked relevant action or process data. Of the 226 that were further examined 30 were found to contain direct quotes relevant to the search parameters and were used to generate the crime script. This was based on specific variables which included: location, full script, phases of script, one instance, multiple instances, individual, group, community, actions, and additional notes.

When examining each entry, special consideration was given to explicit details of how the looting, transit, or market of the object occurred. The variables used attempted to identify important elements within each entry such as the how, what, why, when, and where.

\section{Script development}

A broad ATNs script developed during the author's doctoral work was used as an initial model, but then modified to reflect the specific nature of antiquities trafficking during the Syrian conflict (Weirich 2019). This script represents a potential, or hypothetical script of possible options (as indicated by the data) for how antiquities trafficking occurred during the Syrian conflict. As a result, this script is constrained not only to the data that was available, but also the realities of a civil war. This crime script was created with the aim of using the lessons learned from this conflict, to help better prepare for future conflicts and the protection of cultural heritage (Fig. 2).

Within the Syria data, much of the data represented a more complete perspective of each phase, with articles identifying either individual or multiple stages. While initially the ATNs script was used as a basis for the Syria script, a new specific script quickly emerged, which reflected (as accurately as the dataset allowed) the structure of antiquities trafficking during the Syrian conflict. This data represents a snapshot of the most frequent types of looting, trafficking, and marketing within Syria, which presents a valuable research opportunity, regardless of its shortcomings. The resulting analysis was dependent upon individual scripts being completed with information gathered from the article, with particular attention paid to direct quotations from individuals. As a result, some of the scripts that were used are not fully complete but help to demonstrate a general narrative of how looting might occur.

\section{Results: the Syria crime script}

The decision to use crime script analysis to better understand Syrian antiquities trafficking was a direct result of their efficiency in highlighting trends or patterns for a particular type of crime being committed (Cornish 1994; Wortley and Mazerolle 2013). In this section we present the Syrian crime script for antiquities trafficking, with each phase of the overall script examined in detail. Following conventional practice, the results will be discussed in terms of (a) the looting phrase; (b) transmission phase; and (c) the market phase.

\section{Syria looting phase script}

This detailed script provides a more in-depth analysis of the steps necessary for looters to take in order to engage in antiquities looting. These seven steps represent the minimum actions required for those engaging in illicit antiquities looting in Syria (Fig. 3).

In this section, only three of the seven stages will be examined in detail: acquire tools/labour, access site, and dispose of object. These stages will be examined more thoroughly as a result of representing conditions or scenarios specific to Syria.

\section{Subsistence versus profit looters}

Within the data, a distinction became apparent concerning the types of looters that were participating in the looting of antiquities: subsistence looters and profit looters. The Syrian conflict has left many without a means of income as a result of the fighting and instability within the country (Hokayem 2013; Yassin-Kassab and Al-Shami 2016). It could be argued that all non-profit type looters within Syria are subsistence looters, while some may view the issue as more complex. What is evident is that the most prominent perspective of looters was that of looting to survive: “'They're probably selling most of it,' he said. The looting itself usually happens in a matter of days. Much of the digging is probably done by local people who are 'just trying to feed their families', Danti said." (Drennan 2014) This dataset also reflected a compilation of reports which detail groups of all natures engaging in looting (regime, rebels, terrorists), though many of the journalistic interviews focused on highlighting reports specifically of terrorist organisations: 


\begin{tabular}{|c|c|c|c|c|}
\hline & \multicolumn{4}{|c|}{ Antiquities Trafficking Networks Crime Script } \\
\hline \multirow{5}{*}{ 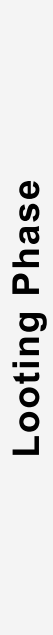 } & Stages & \multicolumn{3}{|c|}{ Profit, Subsistence, or Leisure } \\
\hline & Entry/Action & \multicolumn{3}{|c|}{$\begin{array}{l}\text { Access Site } \\
\text { - Intentionally } \\
\text { - Unintentionally }\end{array}$} \\
\hline & Action & \multicolumn{3}{|c|}{$\begin{array}{l}\text { Search and Find Objects } \\
\text { - Chance } \\
\text { - Anticipated } \\
\text { - Certain }\end{array}$} \\
\hline & Action & \multicolumn{3}{|c|}{$\begin{array}{l}\text { Loot Objects (Remove from location) } \\
\text { - Openly } \\
\text { - Clandestinely }\end{array}$} \\
\hline & Exit & \multicolumn{3}{|l|}{ Dispose of Object } \\
\hline \multirow{5}{*}{ 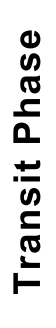 } & & \multicolumn{3}{|c|}{ Smuggler } \\
\hline & Entry/Action & \multicolumn{3}{|l|}{ Obtains Object } \\
\hline & Prep & \multicolumn{3}{|l|}{ Transit Decision } \\
\hline & Action & \multicolumn{3}{|c|}{ Smuggles/Transports object across border } \\
\hline & Exit & \multicolumn{3}{|c|}{ Delivers OR sells object } \\
\hline \multirow{5}{*}{ 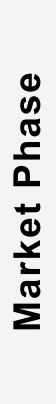 } & & Middleman & & Broker \\
\hline & Entry/Action & Purchases Object & Entry/Action & Purchases Illicit Antiquity \\
\hline & Action & Contacts Buyer & Prep & $\begin{array}{l}\text { Research/Assesses } \\
\text { Object }\end{array}$ \\
\hline & Action/Exit & $\begin{array}{l}\text { Sells Object to } \\
\text { Buyer }\end{array}$ & Prep & Provenance Decision \\
\hline & & & Action/Exit & Sell Object \\
\hline
\end{tabular}

Fig. 2 Antiquities Trafficking Network Crime Script

It's often difficult to definitively determine who is responsible for an instance of looting. Both the Syrian government and rebel groups have taken part, as have locals in both Syria and Iraq whose livelihoods have been disrupted by the conflict. Satellite images and informants on the ground often can't keep up with the pace of looting and of the exchange of territory between various groups. Nonetheless, it's clear that the scale of the Islamic State's destruction, looting, and profits from antiquities trafficking is "unprecedented," Danti said. (Drennan 2014)
For the purposes of this crime script and as a result of the Syrian conflict, civilian looters who engage in looting to provide resources or money for themselves or their family will be categorised as subsistence looters. Any individual associated with an organised group engaged in looting will be categorised as a for-profit looter.

\section{Acquire tools/labour}

There seems to be a rather distinct divide between specialized types of tools (including bulldozers, metal detectors, saws, or drills) and simple tools (shovels, buckets, 


\begin{tabular}{|c|c|c|}
\hline & \multicolumn{2}{|r|}{ Subsistence and Profit Looters } \\
\hline \multirow{7}{*}{ 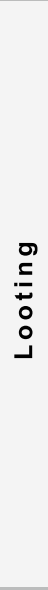 } & Entry & $\begin{array}{l}\text { Select Location } \\
\text { - Search in culturally rich areas }\end{array}$ \\
\hline & Prep & $\begin{array}{l}\text { Acquire Tools/Labour } \\
\text { - Simple } \\
\text { - Specialized }\end{array}$ \\
\hline & Action & $\begin{array}{l}\text { Access Site } \\
\text { - Openly } \\
\text { - Clandestinely }\end{array}$ \\
\hline & Action & $\begin{array}{l}\text { Search \& Find Objects } \\
\text { - Objects made visible/Random find } \\
\text { - Uses advanced knowledge to locate } \\
\text { objects }\end{array}$ \\
\hline & Action & Loot Objects \\
\hline & Action & Transport from Site \\
\hline & Exit & $\begin{array}{l}\text { Dispose of Object } \\
\text { - Sell to Buyer } \\
\text { - Sell to Broker/Dealer } \\
\text { - Smuggle }\end{array}$ \\
\hline
\end{tabular}

Fig. 3 Syria Looting Crime Script fell into one of two categories: those looting and selling their objects to international criminal organisations, and those looting and selling onto middlemen or brokers. Either option would likely result in the objects being transported outside Syria, with the looters either selling directly to buyers (either through the internet or social media/texting platforms) or selling the object onto a broker or dealer (potentially via a smuggler).

The next section will detail this more thoroughly, but initial destinations for looted objects seems to be Turkey, though other potential destinations include Lebanon and Iraq. We can therefore deduce that there exists a significant criminal market for antiquities within these border countries, and therefore are likely high number of middlemen and potential brokers operating in such markets. "The Islamic State profits nearly immediately, selling the goods to middlemen who then smuggle them into neighboring countries such as Turkey, Jordan, and Lebanon, according to Al-Azm." (Drennan 2014).

or pickaxes). This distinction reflects the type of looting that occurred (subsistence versus profit), but also indicates some scale of looting-as specialized equipment would indicate a large-scale looting effort, while simple tools would indicate a smaller operation or scale of looting. The table below (Figure 4) provides some examples from the dataset demonstrating the types of looting and labourers which have been employed within the conflict.

\section{Access site}

While there have been reports of looting occurring in the open, it also appears that the particular region (or group in control of a region) may have some impact on if looters operate in the open, or in a clandestine fashion. It appears that some groups have outlawed looting, with severe punishment for any caught engaging in such activities (Shabi 2015).

\section{ISIS allowed civilians with the knowhow to dig on their own, granting them special permission and charging a 20\% tax, Abu Karim said. He also said that ISIS employed special teams to target high value sites. Experts and sources on the black market supported both of these ideas. (Giglio and al-Awad 2015)}

This may encourage some to loot clandestinely to evade paying the tax.

\section{Disposal of object}

The last stage of this phase (disposal of the object) is concerned with the next destination for the object. A general trend that emerged from the data concerned the types of individuals engaging in antiquities looting. They

\section{Syria transit phase script}

Similar to the looting phase, this section will explore only a few stages in detail as a result of limited data. These stages-preparation of object, smuggling, and destination of the object-tend have more detailed data available, likely as a result of being the more relevant and necessary stages of this phase (Fig. 5).

\section{Smuggler}

Typically, an object is transported from its site or location of origin before being sold or traded, and as such, a smuggler is often required at some point in the process. The role of smuggler can be an individual person or can be taken on by an individual playing multiple roles (For example Looter/Smuggler or Smuggler/Middleman). This role simply represents an action of illegally or covertly transporting an antiquity. It is a rather traditional role when it comes to illicit networks, and some smugglers engage in the transit of various types of objects (weapons, guns, drugs, and people).

\section{Prepares object}

The decisions of whether an object needs to be disguised or concealed can be indicative of how a smuggler operates, how they are intending to smuggle an object, and the type of object being smuggled. For cases in Syria, there is a lack of data pertaining to smuggling specifically, but enough data exists generally to make deductions relating to how much preparation of an object takes place. Within Syria, there is a distinct lack of evidence that smugglers are attempting to hide objects, a result of less secure borders from the conflict, which in turn has been exasperated by the migration crisis (Hardy 2016). 


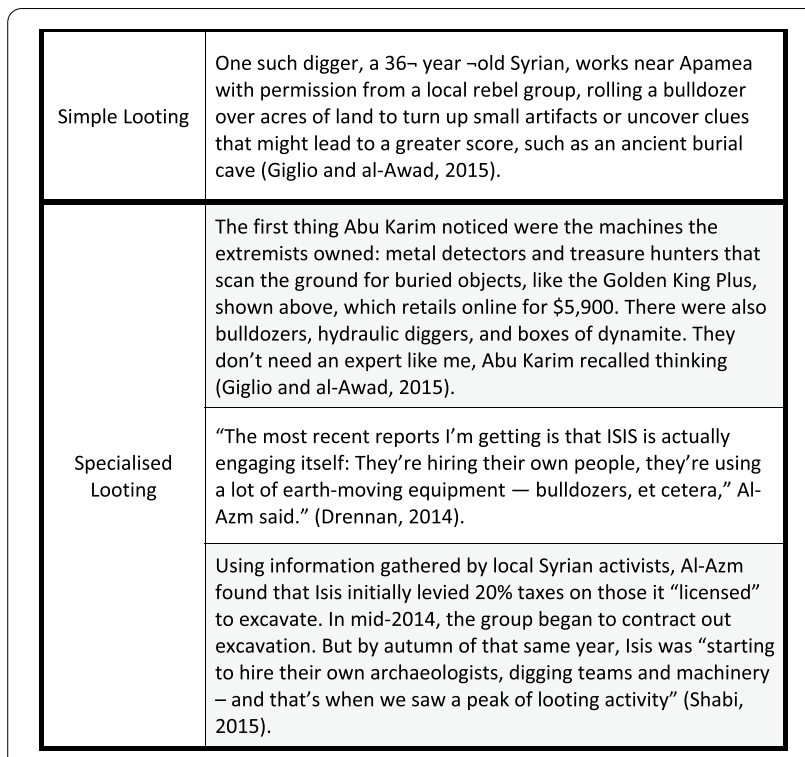

Fig. 4 Types of Looting and Labourers Employed

\section{Smuggles over border}

The transit phase represents the area of antiquities trafficking that typically has the least amount of data or information but this is especially true for the Syria conflict. References to transporting or smuggling an object across a border, is phrased in vague terms, with an assumption of lax border control as a result of the conflict. However, some of the terrorist groups implement stricter laws or regulation of antiquities as is evident in the following quote:

The looter said he had lost the busts to ISIS because he'd used a smuggler who flouted the strict rules the militant group imposes on the territory it controls. The smuggler had been smoking a cigarette when he pulled into an ISIS checkpoint outside Aleppo, en route to Lebanon. This caused the militants to become suspicious, since they consider smoking a sin, and they decided to search the car, finding the busts inside (Giglio and al-Awad 2015).

In the same turn, "Locals will go out and excavate for antiquities and bring this stuff to Isis and get paid, or they're willing to traffic this stuff and pay Isis a tax to smuggle it into Turkey." (Hunter 2015) It appears that at times these terrorist organisations will encourage or facilitate the smuggling of items out of the country, as long as they can profit from it, and it does not clash with their ideological principles.

\section{Destination of object}

The majority of interviews that were conducted by journalists appear to have taken place in Turkey which would indicate that Turkey is indeed a transit destination for many of the objects. Some of the data reveals further destinations such as Europe, Saudi Arabia, and Lebanon (Cornwell 2016; Cox 2015; Meyers and Kulish 2016; Shabi 2015).

'There appears to be an interesting geographic divide: Pre-Islamic objects go to Europe and North America, while Islamic art goes to countries of the gulf, said Markus Hilgert, director of the Museum of the Ancient Near East in Berlin, who is coordinating a research project on the illicit trade. (Meyers and Kulish 2016)

Iraq and Lebanon, which also border Syria, have been identified as transit countries for many objects, though as noted above Turkey offers access to Europe, and there are also reports of objects being transported among similar routes by which migrants were making their way to Europe (Cox 2015; Hunter 2015).

Looted goods are "coming out through Turkey and Beirut and then containered [source typo] to who knows where." By the time an object gets to London, he [David Gill, professor of archaeological heritage at University Campus Suffolk] says, it "has paperwork, internally, within Europe”. (Shabi 2015).

This demonstrates that objects being looted and smuggled from Syria are destined for varied destinations, making the possibility of documenting or recovering such objects even more difficult.

\section{Syria market phase script}

Three of the more prevalent stages within the market phase will be explained, though in a similar fashion to the looting phase, the market phase is enacted through two roles; a middleman and a broker (Fig. 6).

\section{Middleman versus broker}

The fundamental difference between a middleman and a broker is that a middleman works primarily with objects that are still considered illicit. They operate in a manner traditionally similar to those who engaged in a criminal network or market. In contrast, a broker represents an individual who works or engages with objects that are (at this point in the network) licit objects. They represent the transformative stage of when an object moves into the 


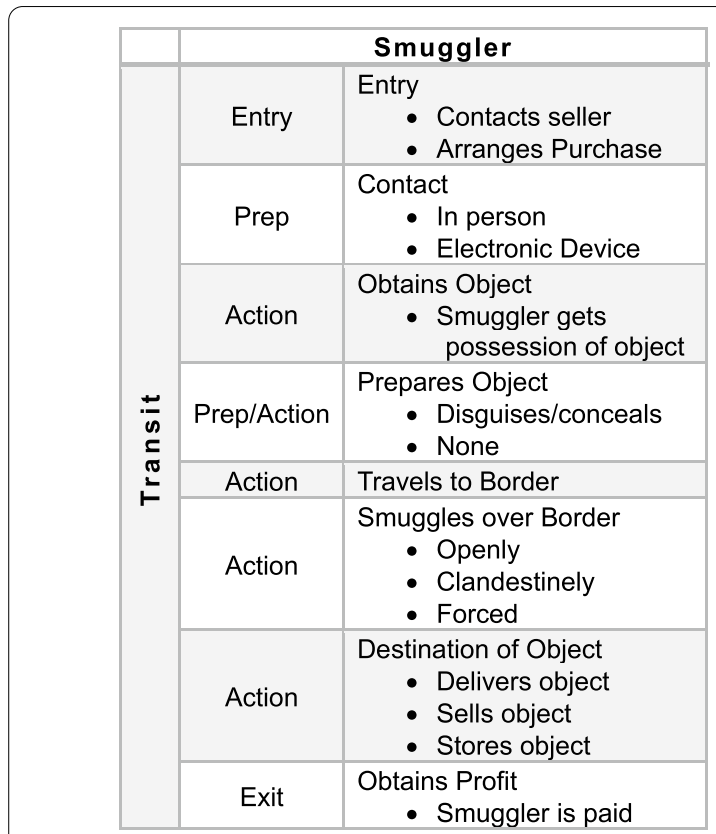

Fig. 5 Syria Transit Crime Script

legitimate market. In the case of Syria, the majority of the dataset reflected the presence of middlemen-individuals who were working in an illegal or illicit capacity.

\section{Provenance decision}

Throughout the available data, there was little mention of provenance. This is likely a direct result of many actors representing the role of middlemen - not brokers-and as such being able to openly sell illicit objects to other middlemen, brokers, or collectors who willingly purchase illicit antiquities.

\section{Arranges buyer}

Many of the news articles described the use of mobile phones during the process of selling objects through displaying wares, communication, organisation of meetings, and even completing transactions (Giglio and al-Awad, 2015; Hunter 2015; Meyers and Kulish 2016). Using a mobile phone, and specifically international texting and communication platforms such as WhatsApp demonstrate a new form of communicating with potential clients as a means of presenting or examining an object.

This data demonstrates that the advancement of technology has changed how connections and relationships operate, which traditionally would have required a more time consuming personal or business relationship-evident in the success of traffickers such as Giacomo Medici, Robert Hecht, and Subhash Kapoor (Felch 2013; Watson and Todeschini 2006). Typically, this process would

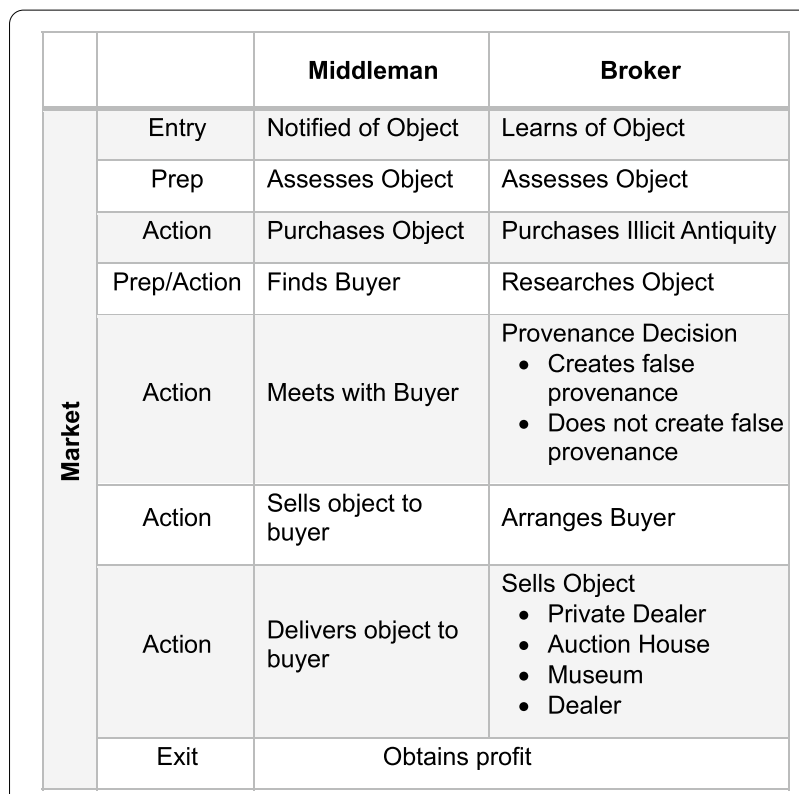

Fig. 6 Syria Market Script

involve having to determine an interested buyer, attempt to determine if they could be considered a trusted buyer, showing them the object (or photos), and arranging a transaction. While this process still exists, the ability to communicate to a large number of interested buyers, from a conflict zone, with only a cell phone has created an expedited process for accessing buyers. Even in the middle of a conflict zone traffickers can reach a global market of buyers and sellers through the use of secure messaging technology, such as WhatsApp. As law enforcement is unable to access encrypted communication, these secured messaging services provide a free and safe environment for communication or illicit transactions (Endeley 2018). Online auction sites and communities dedicated to antiquities sales and purchases, also offer a new venue by which looters, middlemen, and brokers can arrange for the sale of their objects with little risk to themselves (Brodie 2015b).

\section{Sells object}

Much of the data reflected that most of the objects that were sold went on to other middleman-like figures and remained illicit antiquities. This was likely a result of the source of the data, as well as the manner by which it was collected, but still provides a valuable insight into parts of ATNs. It is very likely that, in light of the current embargo on Syrian objects, many of these objects will at some later point enter the legitimate art market-either having been stored until an appropriate time, or after having been in the collection of a private collector (Brodie 2015a; Brodie and Sabrine 2018). 


\begin{tabular}{|c|c|c|c|}
\hline \multicolumn{4}{|c|}{ Syria Antiquities Trafficking Crime Script } \\
\hline \multirow{8}{*}{ בְ } & \multicolumn{3}{|c|}{ Subsistence or Profit Looter } \\
\hline & Entry & \multicolumn{2}{|c|}{ Select Location } \\
\hline & Prep & \multicolumn{2}{|c|}{ Acquire Tools/Labour } \\
\hline & Action & \multicolumn{2}{|c|}{ Access Site } \\
\hline & Action & \multicolumn{2}{|c|}{ Search \& Find Objects } \\
\hline & Action & \multicolumn{2}{|c|}{ Loot Objects } \\
\hline & Action & \multicolumn{2}{|c|}{ Transport from Site } \\
\hline & Exit & \multicolumn{2}{|c|}{ Dispose of Object/Obtains Profit } \\
\hline \multirow{9}{*}{ 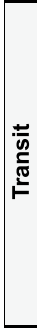 } & \multicolumn{3}{|c|}{ Smuggler } \\
\hline & Entry & \multicolumn{2}{|c|}{ Entry } \\
\hline & Prep & \multicolumn{2}{|c|}{ Contact } \\
\hline & Action & \multicolumn{2}{|c|}{ Obtains Object } \\
\hline & Prep/Action & \multicolumn{2}{|c|}{ Prepares Object } \\
\hline & Action & \multicolumn{2}{|c|}{ Travels to Border } \\
\hline & Action & \multicolumn{2}{|c|}{ Smuggles over Border } \\
\hline & Action & \multicolumn{2}{|c|}{ Destination of Object } \\
\hline & Exit & \multicolumn{2}{|c|}{ Obtains Profit } \\
\hline \multirow{9}{*}{ 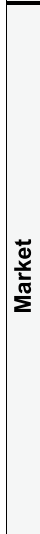 } & & Middleman & Broker \\
\hline & Entry & Notified of Object & Learns of Object \\
\hline & Prep & Assesses Object & Assesses Object \\
\hline & Action & Purchases Object & Purchases Illicit Antiquity \\
\hline & Prep/Action & Finds Buyer & Researches Object \\
\hline & Action & Meets with Buyer & $\begin{array}{l}\text { Provenance Decision } \\
\text { - Creates false provenance } \\
\text { - Does not create false } \\
\text { provenance }\end{array}$ \\
\hline & Action & Sells object to buyer & Arranges Buyer \\
\hline & Action & $\begin{array}{l}\text { Delivers object to } \\
\text { buyer }\end{array}$ & $\begin{array}{l}\text { Sells Object } \\
\text { - Private Dealer } \\
\text { - Auction House } \\
\text { - Museum } \\
\text { - Dealer }\end{array}$ \\
\hline & Exit & \multicolumn{2}{|c|}{ Obtains profit } \\
\hline
\end{tabular}

Fig. 7 Syria Antiquities Trafficking Crime Script (2014-2016)

\section{Discussion}

As the previous section demonstrated, the Syrian antiquities trafficking script is complex, with various means of opportunity and ability. In Figure 7 the script in its entirety is presented, with the progression between the three stages visible. While this script attempt to provide as much detail as possible, it still represents a broad understanding of how antiquities trafficking operated in Syria during the Syrian Civil War. From this script we can better understand the necessary steps that individuals reported to have occurred and provide a framework for understanding that can offer insight for the prevention of antiquity trafficking in future conflict zones.

In considering this script in its entirety some of the limitations faced in this project should be noted, including inherent data bias, language, and conflict zones.

In the case of using journalistic articles, there runs the risk of political or nationalistic bias. The dataset used to construct the Syria scripts is likely politically biased, as there are several international agendas on the table when it comes to the Syrian conflict. This also includes a media bias as this dataset was created with the intent of media consumption and/or promotion. As journalists do not employ academic or scientifically rigorous sampling techniques, they may be only reporting certain types of individuals-certain types of smugglers or brokers-and the danger (from a research perspective) is that a vitally important aspect has been overlooked.

As has been stated, the search parameters for the data that were used to construct the crime script were limited to English speaking publications. Because of a language barrier, other perspectives cannot be considered or included in this research project, resulting in a less comprehensive understanding of Syrian antiquities trafficking networks.

A rather contentious topic within this field included reports that terrorist organisations were being funded by the sale of illicit antiquities (Daniels and Hanson 2015; Willett 2016). This was supported with reference to a photograph, depicting a document which indicates the holder of the paper is granted the right to loot objects with a specific tax amount being paid to ISIS (Daniels and Hanson 2015; Willett 2016). The result of this photo and additional evidence is the premise that illicit antiquities networks funded terrorist organizations including ISIS (Brodie and Sabrine 2018; Daniels and Hanson 2015; Willett 2016).

This article will not begin to speculate as to the validity of these statements. In some cases, individuals have reported that ISIS did loot antiquities in an organized and specific manner, but as this area is still in dispute, with many layers of political and religious influences at hand, this research project will not consider or make any conclusions about the validity of such statements. This crime script has been developed with specific reference to individual statements, but as the conflict has included many areas being lost and recaptured by different groups within this conflict, the crime scripts will simply refer to 'organized groups', as it cannot confirm specifically which groups were, or were not responsible for organized looting of antiquities.

\section{Conclusions}

The crime script presented here provides a starting point for the use of crime script analysis in the research of antiquities trafficking networks. The volume of research relating to crime prevention is still lacking within this field, and crime script analysis provides a relevant, efficient, and accessible form of analysis that can be considered in a field which includes a wide variety of expertise. Throughout this article, the difficulty of gathering such data to complete this crime script has been discussed. This unfortunately also 
reflects a reality of studying such networks-they are often fragmented and disjointed, with various actors becoming active in the network, or leaving the network, at various stages.

This article has sought to demonstrate, that prevention analysis-such as crime script analysis-can still be relevant and effective even when faced with disjointed types of data and research. We must introduce prevention research-even in an imperfect form-if we hope to actively prevent illicit antiquities, and not resort to reactive measures. The Syrian script provides a basic model of actions essential to traffic an antiquity. With this script there now exists a broad framework that can be expanded upon or altered to meet specific conditions or examples of antiquities looting, transit, or marketing specific to Syrian antiquities trafficking. Crime script analysis provides a versatile framework which researchers and law enforcement alike can utilize to consider further points of intervention against the script actions themselves, and the wider circumstances that facilitate them. If we seek to employ effective prevention measures, we must first understand the actions and motivations which drive this network. Crime script analysis is the method by which this can be achieved and will ultimately result in a better understanding of how we might tackle antiquities trafficking networks.

\section{Acknowledgements}

This research was conducted during the author's doctoral thesis at the University of Glasgow, and she would like to acknowledge and thank her supervisors, Dr Simon Mackenzie, Dr Sarah Armstrong, and Dr Neil Brodie for their guidance and help with the completion of her PhD from which this article is produced. The author would also like to thank the Scottish Centre for Crime and Justice Research (SCCJR) for its support as a research institute throughout her doctoral research.

\section{Authors' contributions}

The author read and approved the final manuscript.

\section{Funding}

No outside funding was used to support this work.

\section{Availability of data and materials}

All data used in this research is publicly available data in the form of journalistic articles.

\section{Declarations}

\section{Competing interests}

The authors declare that they have no competing interests.

Received: 4 December 2020 Accepted: 7 June 2021

Published online: 23 June 2021

\section{References}

Alder, C., \& Polk, K. (2005). The illicit traffic in plundered antiquities. In Handbook of Transnational Crime and Justice (pp. 98-113). https://doi.org/10. 4135/9781412976183.n6

Bilefsky, D. (2017, January 20). ISIS Destroys Part of Roman Theater in Palmyra, Syria. The New York Times. https://www.nytimes.com/2017/01/20/world/ middleeast/palmyra-syria-isis-amphitheater.html
Borrion, H. (2013). Quality assurance in crime scripting. Crime Science, 2(1), 6. https://doi.org/10.1186/2193-7680-2-6

Brayley, H., Cockbain, E., \& Laycock, G. (2011). The value of crime scripting: deconstructing internal child sex trafficking. Policing. https://doi.org/10. 1093/police/par024

Brodie, N. (2011). The market in Iraqi antiquities 1980-2009 and academic involvement in the marketing process. Crime in the Art and Antiquities World, pp. 117-133. https://doi.org/10.1007/978-1-4419-7946-9_7

Brodie, N. (2012). Uncovering the Antiquities Market. Oxford Handbooks Online. https://doi.org/10.1093/oxfordhb/9780199237821.013.0013

Brodie, N., Dietzler, J., \& Mackenzie, S. (2013). Trafficking in cultural objects: An empirical overview. In S. Manacorda \& A. Visconti (Eds.), Beni culturali e sistema penale (pp. 19-30). V\&P Vita e Pensiero

Brodie, N. (2015). Syria and its regional neighbors: a case of cultural property protection policy failure? International Journal of Cultural Property, 22, 317-335. https://doi.org/10.1017/S0940739115000144

Brodie, N. (2015b). The internet market in antiquities. countering illicit traffic in cultural goods: the global challenge of protecting the world's heritage. Countering Illicit Traffic in Cultural Goods: The Global Challenge of Protecting the World's Heritage, 11-20.

Brodie, N. (2018). Illicit antiquities. Encycopedia Britannica Inc.

Brodie, N., \& Sabrine, I. (2018). The illegal excavation and trade of Syrian cultural objects: a view from the ground. Journal of Field Archaeology. https://doi. org/10.1080/00934690.2017.1410919

Casana, J., \& Panahipour, M. (2014). Satellite-based monitoring of looting and damage to archaeological sites in Syria. Journal of Eastern Mediterranean Archaeology and Heritage Studies, 2(2), 25. https://doi.org/10.1353/ema. 2014.0011

Chang, R. M., Kauffman, R. J., \& Kwon, Y. (2014). Understanding the paradigm shift to computational social science in the presence of big data. Decision Support Systems, 63, 67-80. https://doi.org/10.1016/J.DSS.2013.08.008

Chiu, Y. N., Leclerc, B., \& Townsley, M. (2011). Crime script analysis of drug manufacturing in clandestine laboratories: Implications for prevention. British Journal of Criminology. https://doi.org/10.1093/bjc/azr005

Chiu, Y. N., Leclerc, B., \& Townsley, M. (2011). Crime script analysis of drug manufacturing in clandestine laboratories: Implications for prevention. British Journal of Criminology, 51(2), 355-374. https://doi.org/10.1093/bjc/ azro05

Contreras, D. A., \& Brodie, N. (2010). The utility of publicly-available satellite imagery for investigating looting of archaeological sites in Jordan. Journal of Field Archaeology, 35(1), 101-114. https://doi.org/10.1179/009346910X 12707320296838

Cornish, D. B. (1994). Crimes as Scripts. Proceedings of the International Seminar on Environmental Criminology and Crime Analysis, 1, 30-45.

Cornwell, T. (2016). Almost 70\% of smuggled object seized in Syria and Lebanon are fakes, antiquities chief says. The Art Newspaper, August.

Cox, S. (2015). The men who smuggle the loot that funds IS. BBC News. https:// www.bbc.co.uk/news/magazine-31485439.

Crowther-Dowey, C., \& Fussey, P. (2013). Researching crime: approaches, methods and application.

Daniels, B. I., \& Hanson, K. (2015). Archaeological Site Looting in Syria and Iraq: A Review of the Evidence. In Countering Illicit Traffic in Cultural Goodsa (p. 83). ICOM. https://www.obs-traffic.museum/sites/default/files/resso urces/files/Book_observatory_illicit_traffic_versionissuu.pdf\#page $=95$.

de Bie, J. L., de Poot, C. J., \& van Leun, J. P. D. (2015). Shiftingmodus operandiof jihadist foreign fighters from the Netherlands between 2000 and 2013: a crime script analysis. Terrorism and Political Violence. https://doi.org/10. 1080/09546553.2015.1021038

Dehghanniri, H., \& Borrion, H. (2017). Toward a more structured crime scripting method. Proceedings - 2016 IEEE 24th International Requirements Engineering Conference Workshops, REW 2016. https://doi.org/10.1109/REW.2016.61

Drennan, J. (2014). The Black-Market Battleground. Foreign Policy. https://forei gnpolicy.com/2014/10/17/the-black-market-battleground/.

Endeley, R. E. (2018). End-to-end encryption in messaging services and national security — case of whatsapp messenger. Journal of Information Security, 09(01), 95-99. https://doi.org/10.4236/jis.2018.91008

Fabiani, M. R. D. (2016). Strategic vs. Opportunistic Looting: The Relationship Between Antiquities Looting and Armed Conflict in Egypt. https://drum.lib. umd.edu/handle/1903/19024.

Felch, J. (2013). SCOOP: New evidence of stolen idols at the national gallery of Australia|CHASING APHRODITE. Chasing Aphrodite. https://chasingaph 
rodite.com/2013/06/04/scoop-new-evidence-of-stolen-idols-at-the-natio nal-gallery-of-australia/.

Giglio, M., \& al-Awad, M. (2015). This Is How Syrian Antiquities Are Being Smuggled And Sold. Buzzfeed. https://www.buzzfeednews.com/article/mikeg iglio/the-trade-in-stolen-syrian-artifacts.

Gilmour, N. (2014). Understanding money laundering - a crime script approach. The European Review of Organised Crime.

Grove, L., \& Pease, K. (2014). A situational approach to heritage crime prevention. In Heritage Crime (pp. 107-127). Palgrave Macmillan.

Hardy, S. (2016). Illicit trafficking, provenance research and due diligence: the state of the art. March, 23.

Harkin, J. (2016). The Race to Save Syria 's Archaeological Treasures. Smithsonian Magazine2.

Hokayem, E. (2013). Syria's Uprising and the Fracturing of the Levant. Routledge for the International Institute for Strategic Studies.

Hunter, I. (2015). Syria conflict: The illicit art trade that is a major source of income for today's terror groups is nothing new. Independent. https://www.indep endent.co.uk/news/world/middle-east/syria-conflict-the-illicit-art-tradethat-is-a-major-source-of-income-for-todays-terror-groups-is-10204285. html.

Hutchings, A., \& Holt, T. J. (2015). A crime script analysis of the online stolen data market. British Journal of Criminology. https://doi.org/10.1093/bjc/ azu106

Hutchings, A., \& Holt, T. J. (2015). A crime script analysis of the online stolen data market. British Journal of Criminology, 55(3), 596-614. https://doi.org/ 10.1093/bjc/azu106

Jacques, S., \& Bernasco, W. (2013). Drug dealing: Amsterdam's Red Light District. In B. Leclerc \& R. Wortley (Eds.), Cognition and Crime (pp. 144-163). Routledge. https://doi.org/10.4324/9780203083482-17.

Lavorgna, A. (2014). Wildlife trafficking in the Internet age. Crime Science. https://doi.org/10.1186/s40163-014-0005-2

Lavorgna, A. (2015). The online trade in counterfeit pharmaceuticals: new criminal opportunities, trends and challenges. European Journal of Criminology. https://doi.org/10.1177/1477370814554722

Lavorgna, A. (2015). The online trade in counterfeit pharmaceuticals: new criminal opportunities, trends and challenges. European Journal of Criminology, 12(2), 226-241. https://doi.org/10.1177/1477370814554722

Leckie, L., Cunliffe, E., \& Varoutsikos, B. (2017). Towards A Protection of the Syrian Cultural Heritage. http://www.heritageforpeace.org/wp-content/uploads/ 2014/10/Heritage-for-Peace-Int-Actions-report-vol-4-oct-2015-dec-2016. pdf.

Leontiadis, N., \& Hutchings, A. (2015). Scripting the crime commission process in the illicit online prescription drug trade. Journal of Cybersecurity. https://doi.org/10.1093/cybsec/tyv006

Mackenzie, S., Brodie, N., Yates, D., \& Tsirogiannis, C. (2019). Trafficking Culture. Routledge. https://doi.org/10.4324/9781315532219

Maxfield, M. G., \& Babbie, E. R. (2012). Basics of research methods for criminal justice and criminology. Boston: Wadsworth/Cengage Learning.

Meyers, S. L., \& Kulish, N. (2016). 'Broken System' Allows ISIS to Profit From Looted Antiquities. New York Times. https://www.nytimes.com/2016/01/10/ world/europe/iraq-syria-antiquities-islamic-state.html.
Parcak, S., Gathings, D., Childs, C., Mumford, G., \& Cline, E. (2016). Satellite evidence of archaeological site looting in Egypt:2002-2013. Antiquity, 90(349), 188-205. https://doi.org/10.15184/aqy.2016.1

Petrossian, G. A. (2014). Preventing illegal, unreported and unregulated (IUU) fishing: a situational approach. Biological Conservation. https://doi.org/10. 1016/j.biocon.2014.09.005

Polk, K. (2009). Whither criminology in the study of the traffic in illicit antiquities? Criminology and Archaeology: Studies in Looted Antiquities (Oñati International Series in Law and Society), 2005, 13-26.

Polk, K. (2014). The global trade in illicit antiquities: Some new directions? In Heritage Crime: Progress, Prospects and Prevention (pp. 206-223). London: Palgrave Macmillan. Doi:https://doi.org/10.1057/9781137357519

Rayne, L., Bradbury, J., Mattingly, D., Philip, G., Bewley, R., \& Wilson, A. (2017). From above and on the ground: geospatial methods for recording endangered archaeology in the Middle East and North Africa. Geosciences, 7(4), 100. https://doi.org/10.3390/geosciences 7040100

Shabi, R. (2015). Looted in Syria — and sold in London: the British antiques shops dealing in artefacts smuggled by Isis. The Guardian, July, 1-6.

Shukla, R. K., \& Bartgis, E. (2010). Responding to clandestine methamphetamine manufacturing: a case study in situational crime prevention. Criminal Justice Policy Review. https://doi.org/10.1177/0887403409352209

Tompson, L., \& Chainey, S. (2011). Profiling illegal waste activity: using crime scripts as a data collection and analytical strategy. European Journal on Criminal Policy and Research. https://doi.org/10.1007/s10610-011-9146-y

Unal, M. (2009). Application of Situational Crime Prevention to Cross-Border Heroin Trafficking in Turkey. http://rave.ohiolink.edu/etdc/view?acc_num=ucin1 258476034.

Watson, P., \& Todeschini, Cecilia. (2006). The Medici conspiracy: the illicitjourney of looted antiquities, from Italy's tomb raiders to the world's greatest museums. BBS PublicAffairs.

Weirich, C. A. (2019). Situational crime prevention of antiquities trafficking: a crime script analysis. (Doctoral thesis). University of Glasgow. https://doi. org/10.5525/gla.thesis.73012.

Willett, H. D. (2016). III-Gotten Gains: A Response to the Islamic State's Profits from the Illicit Antiquities Market. Arizona Law Review, 58(3), 831-866. http://www.heinonline.org.ezproxy.lib.gla.ac.uk/HOL/Page?collection= journals\&handle $=$ hein.journals/arz58\&id $=854$.

Wortley, R., \& Mazerolle, L. (2013). Environmental criminology and crime analysis: situating the theory, analytic approach and application. In Environmental criminology and crime analysis (p. 18). Willan. https://doi.org/10 4324/9780203118214-12

Yassin-Kassab, R., \& Al-Shami, L. (2016). Burning Country: Syrians in Revolution and War. Pluto Press

\section{Publisher's Note}

Springer Nature remains neutral with regard to jurisdictional claims in published maps and institutional affiliations.

Ready to submit your research? Choose BMC and benefit from:

- fast, convenient online submission

- thorough peer review by experienced researchers in your field

- rapid publication on acceptance

- support for research data, including large and complex data types

- gold Open Access which fosters wider collaboration and increased citations

- maximum visibility for your research: over $100 \mathrm{M}$ website views per year

At BMC, research is always in progress.

Learn more biomedcentral.com/submissions 